\title{
IMPLEMENTASI PROFILE MATCHING UNTUK PEMBERIAN KREDIT KEDUA PADA KOPERASI SIMPAN PINJAM
}

\author{
Agusta Praba Ristadi Pinem \\ Fakultas Teknologi Informasi dan Komunikasi \\ Universitas Semarang \\ Email: agusta.pinem@usm.ac.id \\ Prind Triajeng Pungkasanti \\ Fakultas Teknologi Informasi dan Komunikasi \\ Universitas Semarang \\ Email: prind@usm.ac.id \\ Edi Widodo \\ Fakultas Teknologi Informasi dan Komunikasi \\ Universitas Semarang \\ Email: edi.widodo@gmail.com
}

\begin{abstract}
ABSTRAK
Sistem Pendukung Keputusan (SPK) atau Decision Support System (DSS) merupakan suatu pendekatan (atau metodologi) untuk mendukung pengambilan keputusan. SPK menerapkan metode algoritma dalam penyelesaian masalah. Ada beberapa metode algoritma yang dapat digunakan dalam penyelesaian masalah, salah satunya adalah metode profil matching (GAP). Profil matching adalah sebuah mekanisme pengambilan keputusan dengan mengasumsikan bahwa terdapat tingkat variabel prediktor yang ideal yang harus dipenuhi oleh subyek yang diteliti, bukannya tingkat minimal yang harus dipenuhi atau dilewati. SPK dapat diterapkan dalam berbagai macam bidang, salah satunya adalah bidang koperasi. Salah satu proses bisnis pada koperasi yaitu pemberian kredti bagi nasabah. Berdasarkan profil nasabah pihak koperasi dapat mengabulkan dan bahkan menolak permintaan kredit oleh nasabah. Penelitian ini fokus pada proses pengajuan kredit kedua yang dilakukan nasabah yang sebelumnya pernah mengajukan kredit dan disetujui oleh pihak koperasi.
\end{abstract}

Kata kunci: sistem pendukung keputusan; profil matching (GAP); kredit kedua.

\section{ABSTRACT}

Decision Support System (DSS) is an approach (or methodology) to support decision making. DSS applies algorithm method in solving the problem. There are several algorithmic methods that can be used in problem solving, one of which is the profile matching (GAP). A profile matching is a decision-making mechanism by assuming that there is an ideal predictor variable level to be met by the subject under study, rather than the minimum level to be met or passed. SPK can be applied in various fields, one of which is the field of cooperatives. One of the business processes in the cooperative is giving credit to customers. Based on the customer profile, the cooperative can grant and even refuse credit request by the customer. This study focuses on the process of submitting a second credit made by customers who previously had applied for credit and approved by the cooperative.

Keywords: decision support systems; profil matching (GAP); second credit.

\section{PENDAHULUAN}

Sistem Pendukung Keputusan (SPK) atau Decision Support System (DSS) merupakan suatu pendekatan (atau metodologi) untuk mendukung pengambilan keputusan. DSS menggunakan Computer Base Information System (CBIS) yang fleksibel, interaktif, dan dapat diadaptasi, yang dikembangkan untuk mendukung solusi bagi masalah manajemen spesifik yang tidak terstruktur [1]. SPK menerapkan metode algoritma dalam penyelesaian masalah. Ada beberapa metode algoritma yang dapat digunakan dalam penyelesaian masalah, salah satunya adalah metode profil matching (GAP).

Profil matching adalah sebuah mekanisme pengambilan keputusan dengan mengasumsikan bahwa terdapat tingkat variabel prediktor yang ideal yang harus dipenuhi oleh subyek yang diteliti, bukannya 
tingkat minimal yang harus dipenuhi atau dilewati [2]. Sedangkan GAP adalah proses pengambilan keputusan dengan memilih suatu alternatif dengan menghitung jumlah nilai perbedaan beberapa aspek kriteria atau dengan menghitung kecocokan nilai kriteria [2]. SPK juga diterapkan dalam bidang jasa, salah satunya adalah Koperasi. Koperasi memiliki program simpan pinjam yang ditujukan kepada nasabah yang ingin melakukan peminjaman atau kredit. Dalam menentukan kelayakan pemberian kredit, ada beberapa kriteria yang menjadi tolak ukur sehingga menghindari resiko kredit macet. SPK dapat membantu dalam pengambilan keputusan dengan memberikan informasi terkait kelayakan pemberian kredit. Namun pada penelitian ini lebih dikhususkan pada kelayakan pemberian kredit kedua. Kredit kedua adalah pengajuan kredit setelah sebelumnya pernah melakukan peminjaman pertama. Kriteria yang digunakan berbeda dengan kriteria yang digunakan dalam penentuan kelayakan kredit pertama.

\section{METODOLOGI PENELITIAN}

\subsection{Sistem Pendukung Keputusan}

Sistem Pendukung Keputusan (SPK) atau Decision Support System (DSS) merupakan suatu pendekatan (atau metodologi) untuk mendukung pengambilan keputusan. DSS menggunakan Computer Base Information System (CBIS) yang fleksibel, interaktif, dan dapat diadaptasi, yang dikembangkan untuk mendukung solusi bagi masalah manajemen spesifik yang tidak terstruktur [1]. DSS juga disebut sebagai model sekumpulan prosedur untuk pengolahan data dan penilaian untuk membantu dalam pengambilan keputusan [3].

Kutipan dalam buku Decision Support System and Intelligent System Little (1970) mendefinisikan DSS sebagai "sekumpulan prosedur berbasis model untuk data pemrosesan dan penilaian guna membantu para manajer mengambil keputusan" [1].DSS selain sebagai alat bantu pengambilan keputusan, tapi juga dapat mempercepat konvergensi atau penggabungan proses pengambilan keputusan [4]. Konvergensi pada DSS digunakan untuk mencangkup komponen DSS. DSS memiliki 2 komponen utama, yaitu alternatif dan kriteria. Proses $D S S$ terdiri dari beberapa alternatif dan beberapa kriteria yang diolah untuk memecahkan masalah [2].

\subsection{Profil Matching (GAP)}

Profil matching adalah sebuah mekanisme pengambilan keputusan dengan mengasumsikan bahwa terdapat tingkat variabel prediktor yang ideal yang harus dipenuhi oleh subyek yang diteliti, bukannya tingkat minimal yang harus dipenuhi atau dilewati(3). Dalam proses profile matching secara garis besar merupakan proses membandingkan antara kompetensi alternatif atau individu ke dalam kompetensi sehingga dapat diketahui perbedaan kompetensinya (disebut juga gap), semakin kecil gap yang dihasilkan maka bobot nilainya semakin besar yang berarti memiliki peluang lebih besar untuk dipilih (4).Model matematika GAP adalah proses pengambilan keputusan dengan memilih suatu alternatif dengan menghitung jumlah nilai perbedaan beberapa aspek kriteria atau dengan menghitung kecocokan nilai kriteria(5). Maksud dari pencocokan kriteria adalah sebuah mekanisme pengambilan keputusan dengan mengasumsikan bahwa terdapat tingkat variabel prediktor yang ideal yang harus dimilik oleh suatu obyek yang akan dibandingkan.

Metode profile matching sudah diterapkan pada beberapa kasus dengan menggunakan profil manusia sebagai objek penelitian, yaitu penentuan penerima bantuan rumah miskin(5), penentuan penerima usulan penelitian(6), penentuan kinerja pegawai(5), penentuan kenaikan jabatan [8] dan penentuan penempatan lokasi dinas pegawai(1). Selain itu profile matching lebih sekedar dalam pengurutan, melainkan perangkingan dengan kriteria yang dinamis(3).

Profile matching dibagi menjadi beberapa langkah, yaitu Aspect, Scoring, GAP, Core Factor dan Secondary Factor, Total Weight danRanking(5). Langkah pertama yaitu menentukan aspek atau kriteria yang digunakan. Aspek atau kriteria merupakan variabel yang digunakan dalam metode sistem pendukung keputusan. Aspek-aspek tersebut kemudian dibagi menjadi dua yaitu aspek yang termasuk dalam core factor dan aspek yang masuk anggota secondary factor. Core factor merupakan kriteria utama atau mempunyai nilai pengaruh lebih tinggi, sedangkan secondary factor sebaliknya yaitu kriteria dengan nilai bobot yang lebih kecil atau memiliki pengaruh yang tidak sebesar core factor.

Langkah kedua yaitu penilaian masing-masing aspek dan penentuan nilai target atau nilai profil standar. Selanjutnya adalah mencari nilai GAP. GAP merupakan perbedaan atau selisih antara nilai aspek dan nilai target. Setelah memperoleh nilai $G A P$, maka selanjutnya masing-masing profil alternative diberi bobot. Bobot nilai diperoleh dari selisih atau $G A P$ nilai aspek dengan nilai target. Nilai bobot selanjutnya digunakan untuk memperoleh nilai Core Factor dan Secondary Factor. Nilai Core Factor diperoleh dengan persamaan satudan Secondary Factor diperoleh dengan persamaan dua . 


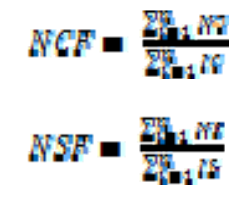

Keterangan :

$\begin{array}{ll}\text { NCF } & : \text { Core Factor Value } \\ \text { NSF } & : \text { Secondary Factor Value } \\ \text { NC } & : \text { Total Weight Core Factor } \\ \text { NS } & \text { : Total Weight Secondary Factor } \\ \text { IC } & : \text { Total Item Core Factor } \\ \text { IS } & : \text { Total Item Secondary Factor }\end{array}$

Nilai Core Factor dan Secondary Factor kemudian digunakan untuk mencari Nilai Total. Nilai total diperoleh dengan menggunakan persamaan tiga.

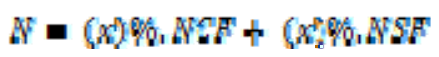

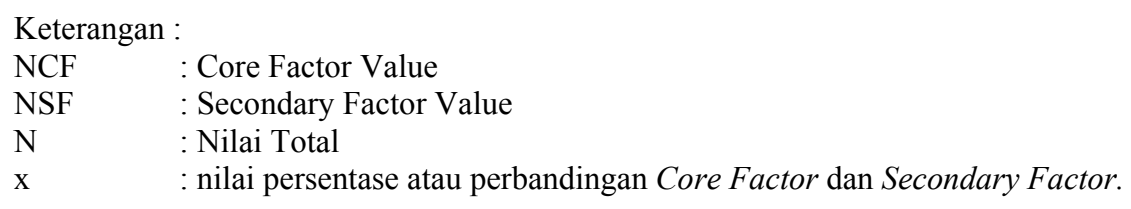

Dari perhitungan setiap aspek yang digunakan, berikutnya dihitung Nilai Total berdasarkan presentase dari core factor dan secondary factor yang diperkirakan berpengaruh terhadap suatu keputusan(3). Nilai Total selanjutnya digunakan sebagai parameter perangkingan setiap alternative sehingga memperoleh alternatif dari yang terbaik hingga alternatif yang nilainya paling rendah.

\subsection{Kelayakan Kredit}

Dalam koperasi simpan pinjam, nasabah dapat melakukan peminjaman atau kredit dengan memperhatikan beberapa variable atau kriteria. Proses penentuan kelayakan pemberian kredit ketika nasabah melakukan peminjaman pertama kali atau disebut kredit pertama, mengacu pada $5 \mathrm{C}$ yang sudah menjadi acuan pemberian kredit di perbankan. $5 \mathrm{C}$ terdiri dari character, capacity, capital, collateral dan condition(7).Namun kriteria tersebut akan sedikit berbeda ketika proses penentuan kelayakan kredit kedua. Pada proses pengajuan kredit pertama, lima aspek tersebut digunakan sebagai variable utama lolos atau tidaknya pengajuan kredit nasabah. Aspek tersebut masih tetap digunakan dalam penentuan kredit kedua namun lebih mempertimbangkan pada riwayat kredit pertama. Berdasarkan observasi lapangan, penelitian ini menggunakan 5 (lima) kriteria dalam menentukan kelayakan pemberian kredit kedua, yaitu:
a) Riwayat nasabah
b) Nilai jaminan
c) Nilai kredit
d) Jangka waktu kredit
e) Usia

Masing-masing kriteria yang dimiliki oleh nasabah akan dibandingkan satu sama lain untuk mengklasifikasi status kelayakan pemberian kredit. Kriteria-kriteria diatas dibagi menjadi core factor dan secondary factor. Pada penelitian ini riwayat kredit menjadi core factor, sedangkan keempat kriteria lain menjadi secondary factor. Riwayat kredit menjadi kriteria utama dikarenakan pada proses pengajuan kredit pertama kriteria-kriteria pada acuan kredit perbankan telah dianalisa. Sedangkan keempat kriteria yang lain tetap menjadi kriteria yang perlu di analisa ulang karena kriteria-kriteria tersebut mengalami penurunan nilai. Sebagai contoh yaitu kriteria jaminan dan umur.

Dalam menentukan nilai aspek, masing-masing nilai setiap kriteria dibuat skala. Skala masingmasing aspek atau kriteria berbeda-beda satu dengan lainnya mengacu pada data yang digunakan. Skala aspek riwayat nasabah berdasarkan pada proses peminjaman pertama ditunjukan pada tabel 1 . 
Tabel 1. Skala aspek riwayat nasabah

\begin{tabular}{cll}
\hline Lama Tunggakan (Hari) & \multicolumn{1}{c}{ Keterangan } & Skala \\
\hline 0 & Lancar & 5 \\
$1-90$ & Dalam Perhatian Khusus & 4 \\
$91-120$ & Kurang Lancar & 3 \\
$121-180$ & Diragukan & 2 \\
$>180$ & Macet & 1 \\
\hline
\end{tabular}

Aspek riwayat nasabah merupakan riwayat angsuran nasabah pada kredit pertama. Lama tunggakan atau kolektibilitas kredit (kualitas kredit) digunakan sebagai acuan penentuan nilai skala. Terdapat lima status kolektibilitas kredit mengacu pada Peraturan Bank Indonesia Nomor: 7/2/PBI/2005 Tentang Penilaian Kualitas Aktiva Bank Umum, sehingga skala yang digunakan yaitu 1 sampai dengan 5.

Aspek nilai jaminan adalah kriteria besaran nilai jaminan pada proses pengajuan kredit kedua. Skala aspek nilai jaminan ditunjukan dengan tabel 2.

Tabel 2. Skala aspek nilai jaminan

\begin{tabular}{lccc}
\hline \multicolumn{2}{c}{ Nilai Jaminan } & Skala \\
\hline Rp1,000,000.00 & - & Rp3,000,000.00 & 1 \\
Rp3,100,000.00 & - & Rp6,000,000.00 & 2 \\
Rp6,100,000.00 & - & Rp9,000,000.00 & 3 \\
Rp9,100,000.00 & - & Rp14,000,000.00 & 4 \\
Rp14,100,000.00 & - & $>$ & 5 \\
\hline
\end{tabular}

Aspek nilai kredit adalah kriteria besaran nilai kredit yang diajukan oleh nasabah pada proses pengajuan kredit kedua. Skala aspek nilai kredit ditunjukan dengan tabel 3.

Tabel 3. Skala aspek nilai kredit

\begin{tabular}{lc}
\hline \multicolumn{1}{c}{ Nilai kredit } & Skala \\
\hline Rp 300.000 - Rp 1.500.000 & 5 \\
Rp 1.600.000 - Rp 3.000.000 & 4 \\
Rp 3.100.000 - Rp 4.500.000 & 3 \\
Rp 4.600.000 - Rp 6.000.000 & 2 \\
Rp 6.000.000 keatas & 1 \\
\hline
\end{tabular}

Aspek nilai jangka jaminan adalah jangka waktu pinjaman yang diajukan oleh nasabah pada proses pengajuan kredit kedua. Skala aspek jangka pinjaman ditunjukan dengan tabel 4.

Tabel 4. Skala aspek jangka pinjaman

\begin{tabular}{ll}
\hline Jangka Pinjaman & Skala \\
\hline 24 Bulan & 5 \\
18 Bulan & 4 \\
12 Bulan & 3 \\
10 Bulan & 2 \\
6 Bulan & 1 \\
\hline
\end{tabular}

Aspek usia merupakan salah satu aspek yang mengalami penurunan nilai. Nilai pada kredit pertama akan menurun ketika proses pengajuan kredit kedua. Skala aspek usia ditunjukan dengan tabel 5.

Tabel 5. Skala aspek usia

\begin{tabular}{lll}
\hline Usia & Status & Skala \\
\hline Dibawah 15 tahun & Belum Produktif & 1 \\
15 tahun - 59 tahun & Produktif & 3 \\
Diatas 59 tahun & Tidak Produktif & 2 \\
\hline
\end{tabular}

Setiap nilai aspek dengan skala yang digunakan memiliki nilai target atau nilai profil standar sebagai pembanding untuk memperoleh nilai GAP. Berikut nilai target masing-masing aspek yang ditunjukan pada tabel 6. 
Tabel 6. Nilai target/ profil standar

\begin{tabular}{ll}
\hline Aspek & Nilai Target \\
\hline Riwayat Nasabah & 4 \\
Nilai Jaminan & 2 \\
Nilai kredit & 4 \\
Jangka Waktu Pinjaman & 3 \\
Usia & 3 \\
\hline
\end{tabular}

Nilai target atau nilai profil standar masing-masing aspek dilihat dari standar atau nilai normal yang digunakan pada koperasi berdasarkan rentang nilai kriteria atau data. Nilai standar dapat sebagai nilai yang sering muncul atau nilai standar pada suatu koperasi. Selisih atau GAP antara nilai aspek dan nilai target digunakan dalam penentuan nilai bobot yang diperoleh masing-masing profil.

\section{HASIL DAN PEMBAHASAN}

\subsection{Hasil Penelitian}

Dalam membangun sebuah sistem, maka diperlukan proses perancangan. Salah satunya dengan menggunakan UML (Unified Modeling Language). Berikut desain sistem dengan Use case diagram yang digunakan untuk menggambarkan kelakuan atau fungsi apa saja yang terdapat dalam sistem. Gambar 1 menggambarkan interaksi actor (pengguna) dengan sistem.

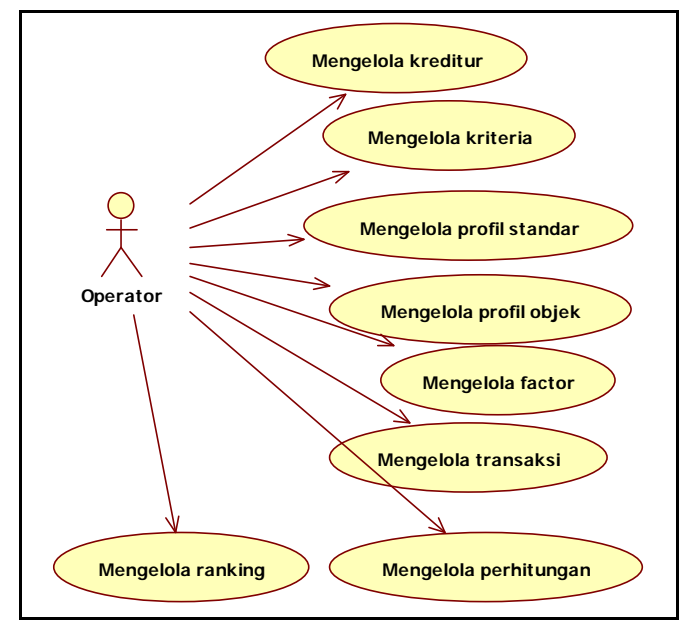

Gambar 1. Usecase Diagram

Data simpan pinjam masih berupa data yang diperoleh dari sistem, selanjutnya data tersebut di olah dan masukan ke skala yang didefinisikan di table 1 hingga 6. Rentang nilai pada data kemudian disesuaikan dengan skala yang digunakan sehingga memunculkan data scoring yang ditunjukan pada tabel 7.

Tabel 7. Data scoring

\begin{tabular}{clccccc}
\hline Al & \multicolumn{1}{c}{ Nama } & Plafon & Jangka & Telat hari & Nilai jaminan & Umur \\
\hline A1 & A.Muchib & 3 & 4 & 5 & 3 & 3 \\
A2 & Djoelaechah & 2 & 3 & 5 & 4 & 3 \\
A3 & Dwi Purnawan & 1 & 2 & 5 & 5 & 3 \\
A4 & Eko Hadi W & 4 & 3 & 5 & 2 & 2 \\
A5 & Ngadiono & 2 & 2 & 5 & 4 & 3 \\
A6 & Dwi Purnawan & 1 & 2 & 5 & 5 & 3 \\
A7 & Giartono & 1 & 2 & 5 & 5 & 3 \\
A8 & Hasrul Suyadi & 1 & 4 & 5 & 5 & 3 \\
A9 & Mustianah & 1 & 5 & 5 & 5 & 3 \\
A10 & M.Solekan & 1 & 5 & 5 & 5 & 3 \\
A11 & Masrokan & 4 & 2 & 4 & 2 & 3
\end{tabular}




\begin{tabular}{clccccc}
\hline \multicolumn{1}{c}{ Nama } & \multicolumn{1}{c}{ Plafon } & Jangka & Telat hari & Nilai jaminan & Umur \\
\hline A12 & M Nuruddin & 3 & 3 & 4 & 3 & 3 \\
A13 & Jaelani & 1 & 5 & 5 & 5 & 3 \\
A14 & Nurarifin & 4 & 3 & 4 & 2 & 3 \\
A15 & Ridwan & 1 & 1 & 5 & 5 & 3 \\
A16 & Rudy Hartanto & 1 & 5 & 5 & 5 & 3 \\
A17 & Shodikin & 4 & 1 & 4 & 2 & 3 \\
A18 & Siti Fatimah & 2 & 3 & 5 & 4 & 3 \\
A19 & Haryono / Wagi & 5 & 2 & 5 & 1 & 2 \\
& Murni & & & & & 3 \\
A20 & Widodo & 1 & 5 & 5 & & \\
\hline
\end{tabular}

Data pada tabel 7, data scoring yang sudah terbentuk menjadi matrik yang kemudian dicari nilai normalisasi hingga total persentase core factor dan secondary factor.

Implementasi sistem merupakan penerapan algoritma dalam metode GAP menjadi sebuah sistem pendukung keputusan berbasis web.Pada halaman analisa kredit, ditampilkan data alternative dan kriteria yang digunakan dalam proses perangkingan dengan metode $G A P$. Kolom plafon yaitu nominal pengajuan pinjaman, kolom jangka yaitu jangka pinjaman, kolom telat merupakan riwayat nasabah pada peminjaman sebelumnya. Gambar 2 menunjukan halaman analisa kredit aplikasi SPK pemberian kredit kedua.

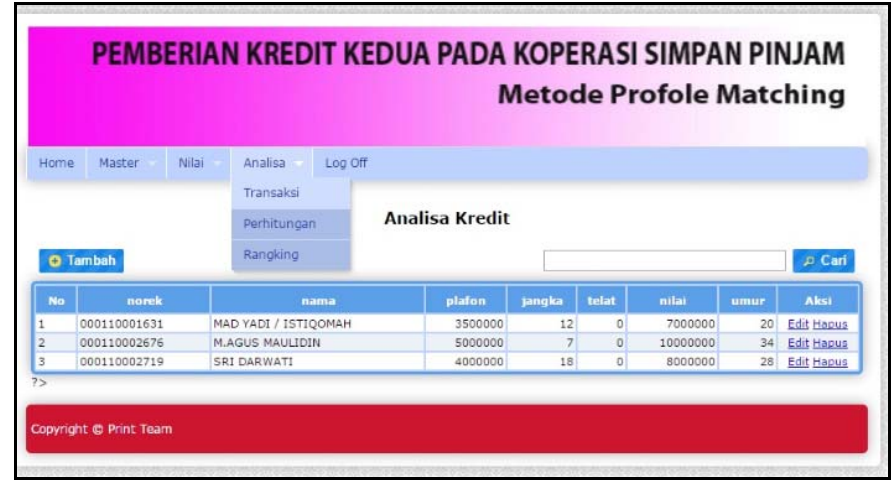

Gambar 2. Halaman Analisa Kredit

Perhitungan GAP diperoleh dari penerapan persamaan 1 hingga 3 pada bahasa pemrograman $P H P$. Gambar 3 memperlihatkan antarmuka perhitungan GAPdari bobot, nilai, total dan obyek.

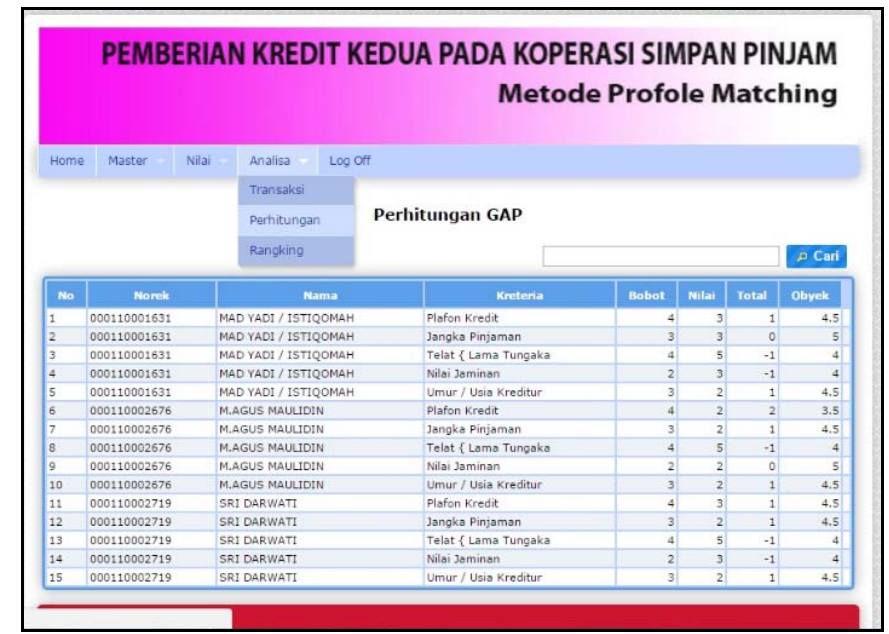

Gambar 3. Halaman Perhitungan GAP 
Hasil perangkingan dengan metode $G A P$ menampilkan peringkat nasabah beserta nilai total berdasarkan lima aspek yang digunakan. Gambar 4 menunjukan halaman perangkingan penerima kredit kedua.

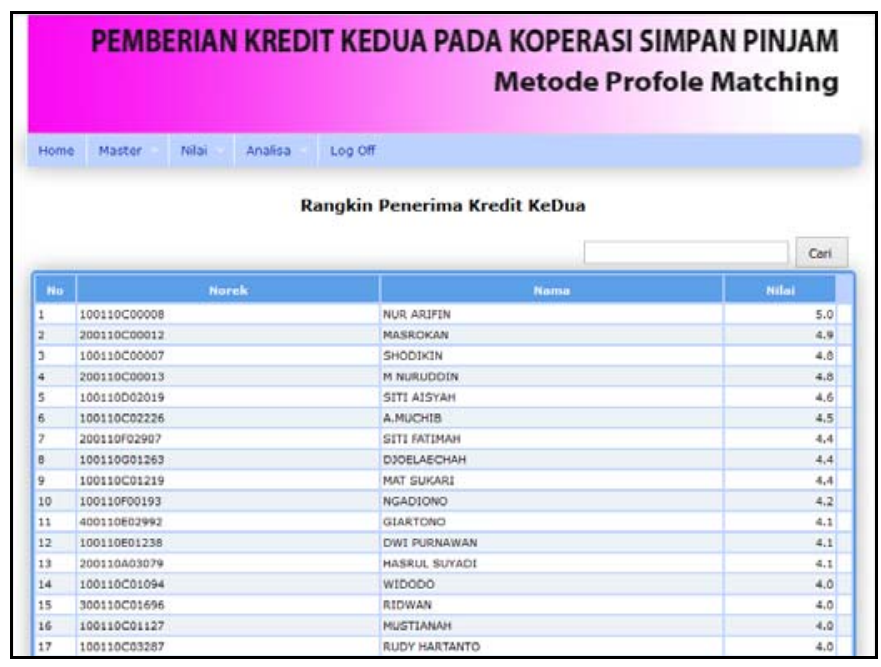

Gambar 4. Hasil Perangkingan GAP

Berdasarkan data sekunder yang diperoleh dari observasi sistem informasi simpan pinjam koperasi selanjutnya data diolah untuk mendapatkan data yang utuh terkait dengan lima aspek yang digunakan. Pada proses perhitungan manual dengan metode profile matching menggunakan 20 data nasabah yang sudah pernah melakukan peminjaman sebelumnya.

Nasabah Nurarifin menjadi nasabah dengan nilai tertinggi. Informasi perangkingan menjadi masukan bagi koperasi simpan pinjam untuk menentukan kelayakan penerima kredit. Table 8 merupakan hasil perangkingan dengan metode profile matching berdasarkan lima aspek data simpan pinjam yang digunakan.

Table 8. Hasil perangkingan

\begin{tabular}{lrc}
\hline Nama & Nilai & Rangking \\
\hline Nurarifin & 5 & 1 \\
Masrokan & 4.9 & 2 \\
M Nuruddin & 4.85 & 3 \\
Shodikin & 4.8 & 4 \\
Siti Aisyah & 4.6 & 5 \\
A.Muchib & 4.5 & 6 \\
Djoelaechah & 4.35 & 7 \\
Siti Fatimah & 4.35 & 7 \\
Mat Sukari & 4.35 & 7 \\
Ngadiono & 4.25 & 10 \\
Hasrul Suyadi & 4.1 & 11 \\
Dwi Purnawan & 4.05 & 12 \\
Dwi Purnawan & 4.05 & 12 \\
Giartono & 4.05 & 12 \\
Mustianah & 4 & 15 \\
M.Solekan & 4 & 15 \\
Jaelani & 4 & 15 \\
Rudy Hartanto & 4 & 15 \\
Widodo & 4 & 15 \\
Ridwan & 3.95 & 20 \\
\hline
\end{tabular}

Berdasarkan hasil perhitungan pada sistem dan perhitungan manual menunjukan kesesuain output yang dihasilkan, yaitu output rangking dan nilai total dari persentase core factor dan secondary factor. 


\section{KESIMPULAN}

Kesimpulan yang dapat ditarik dari penelitian ini adalah telah terbentuknya sebuah sistem pendukung keputusan dalam bidang simpan pinjam. Yaitu sistem pendukung keputusan untuk penentuan kelayakan proses pengajuan kredit kedua dengan menggunakan metode Profile Matching (GAP).

a) Hasil dari sistem ini telah diuji dan diverifikasi, dengan hasil menunjukan bahwa sistem pendukung keputusan menghasilkan output yang sama dalam segi perhitungan pada metode Profile Matching.

b) Sistem ini dapat mengembangkan model penentuan prioritas nasabah yang layak untuk diberikan

\section{DAFTAR PUSTAKA}

[1] Turban, E., et. al.(2005).Decision Support System and Intelligent Systems (Sistem Pendukung Keputusan dan Sistem Cerdas), Edisi 7 Jilid 1, Andi, Yogyakarta

[2] Z. Tharo and A. P. Utama Siahaan. 2016. "Profile Matching in Solving Rank Problem." IOSR J. Electron. Commun. Eng., vol. 11, no. 05, pp. 73-76.

[3] R. Nasriyah, Z. Arham, and Q. Aini. 2016. "Profile Matching and Competency Based Human Resources Management Approaches for Employee Placement Decision Support System (Case Study)." Asian J. Appl. Sci., vol. 9, no. 2, pp. 75-86.

[4] C.-S. Wang, H.-L. Yang, and S.-L. Lin. 2015. "To Make Good Decision: A Group DSS for Multiple Criteria Alternative Rank and Selection”.Math. Probl. Eng., vol. 2015, pp. 1-15.

[5] M. I. Nashrullah, G. Abdillah, and F. Renaldi. 2016. "Sistem Pendukung Keputusan Untuk Rekomendasi Promosi Jabatan Menggunakan Metode Profile Matching Dan Electre." Pros. SNST Fak. Tek., vol. 1, no. 1.

[6] H. A. Hasibuan, R. B. Purba, and A. P. U. Siahaan. 2016. "Productivity Assessment (Performance, Motivation, and Job Training) Using Profile Matching”.SSRG Int. J. Econ. Manag. Stud., vol. 3, no. 6, pp. 73-77.

[7] E. F. S. E. R. YogyakartaSTMIK and others. 2014. "Implementasi Metode Profile matching untuk Penentuan Penerimaan Usulan Penelitian Internal Dosen STMIK El Rahma".Speed-Sentra Penelit. Eng. Dan Edukasi, vol. 6, no. 1, 2014.

[8] Muqtadir. Asfan dan Purdianto. Irwan., 2013."Sistem Pendukung Keputusan Kenaikan Jabatan Menggunakan Metode Profile Matching (Studi Kasus PT. Industri Kemasan Semen Gresik)".Seminar Nasional Aplikasi Teknologi Informasi (SNATI) Yogyakarta.

[9] N. M. D. Widiantari, I. W. Suwendra, F. Yudiaatmaja, and others. 2014. "Pengaruh Penilaian Kredit Terhadap Keputusan Pemberian Kredit Pada BPR”.J. Jur. Manaj., vol. 2, no. 1, 2014. 